Research

\title{
The Effect of Age and Breed on The Quality of Bull Semen in The Regional Artificial Insemination Centre
}

\author{
Agung Budiyanto ${ }^{*}$, Makruf Arif ${ }^{2}$, Mandala Phivi Whelma Alfons ${ }^{2}$, Rifia Tiara Fani², \\ Ardian Faiz Hafid ${ }^{3}$, Brian Wicaksono3, Kharisma Mutiara Insani ${ }^{3}$, Migi Herdinta ${ }^{3}$ \\ 'Department of Reproduction and Obstetrics, Faculty of Veterinary Medicine, \\ Universitas Gadjah Mada, Jl. Fauna 2 Karangmalang, Sleman, Yogyakarta, 55281 \\ ${ }^{2}$ Postgraduate Student of Veterinary Science, Faculty of Veterinary Medicine, Universitas Gadjah Mada, \\ Jl. Fauna 2 Karangmalang, Sleman, Yogyakarta, 55281 \\ 3 Undergraduate Student of Veterinary Medicine, Faculty of Veterinary Medicine, Universitas Gadjah Mada, \\ Jl. Fauna 2 Karangmalang, Sleman, Yogyakarta, 55281 \\ *Corresponding author: budiyanto@ugm.ac.id \\ Submitted April 2, 2021 Accepted May 9, 2021
}

\begin{abstract}
The success of beef cattle reproduction development in Indonesia very much depends on the quality of the semen produced by the Indonesian Institute for Artificial Insemination. Good quality bull will benefit farmers, frozen semen producers, and the country in large. This study aimed to determine effect of age and breed on the libido and quality of bull semen collected in the Regional Artificial Insemination Center (RAIC). This study used PO, Simmental, and Brahman Bull in RAIC Yogyakarta, with a total amount of 15, aged 4-7 years old. Semen was collected using an artificial vagina, semen evaluation used a spectrophotometer, and eosin-nigrosin staining method used for sperm viability and abnormalities examination. The result of this study indicated that bull breed did not affect the libido value and the semen quality of bulls $(P>0,05)$. Volume, concentration, motility, and viability in various age groups did not show significant differences $(P>0,05)$, but age groups had a significant effect on sperm abnormalities $(\mathrm{P}<0,05)$. The group of bulls aged 5-6 years showed the best quality compared to other groups, with the volume 4,58 $\pm 1,37 \mathrm{ml}$, concentration $1,91 \pm 0,36 \times 10^{9} / \mathrm{ml}$, motility $3,80 \pm 1,30$, viability 89.83 $\pm 10.69 \%$, and sperm abnormalities $2.51 \pm 0.81 \%$. It can be concluded that breed did not affect the bull libido and semen quality, while age had an effect on bull sperm abnormalities.
\end{abstract}

Keywords: age, breed, bull, libido, semen quality

\begin{abstract}
ABSTRAK
Keberhasilan pengembangan reproduksi sapi potong di Indonesia sangat bergantung pada kualitas semen yang diproduksi oleh Balai Inseminasi Buatan di Indonesia. Sapi jantan yang berkualitas akan menguntungkan peternak, produsen semen beku, dan negara. Penelitian ini bertujuan untuk mengetahui pengaruh umur dan breed (jenis) terhadap libido dan kualitas semen sapi potong yang dikoleksi di Balai Inseminasi Buatan Daerah. Penelitian ini menggunakan 15 ekor sapi jenis PO, Simmental, dan Brahman di UPTD BPBPTDK Yogyakarta, dengan umur 4-7 tahun. Semen dikoleksi menggunakan vagina buatan, kemudian evaluasi semen menggunakan spektrofotometer, dan metode pewarnaan eosin nigrosine untuk pemeriksaan viabilitas dan abnormalitas spermatozoa. Hasil penelitian menunjukkan bahwa bangsa sapi jantan tidak berpengaruh terhadap nilai libido dan kualitas semen yang dihasilkan $(P>0,05)$. Volume, konsentrasi, motilitas, dan viabilitas pada berbagai kelompok umur tidak menunjukkan perbedaan yang nyata $(\mathrm{P}>0,05)$, tetapi kelompok umur berpengaruh signifikan terhadap abnormalitas spermatozoa $(\mathrm{P}<0,05)$. Kelompok sapi jantan umur 5-6 tahun menunjukkan kualitas semen paling baik, dengan volume 4,58 $\pm 1,37 \mathrm{ml}$, konsentrasi 1,91 $\pm 0,36 \times 10^{9} / \mathrm{ml}$, motilitas $3,80 \pm 1,30$, viabilitas $89.83 \pm 10.69 \%$, dan abnormalitas spermatozoa $2.51 \pm 0.81 \%$. Dapat disimpulkan bahwa bangsa sapi tidak mempengaruhi nilai libido dan kualitas semen, sedangkan umur hanya berpengaruh pada nilai abnormalitas spermatozoa.
\end{abstract}

Kata kunci: bangsa, kualitas semen, libido, sapi pejantan, umur 


\section{INTRODUCTION}

Breeding activities are one of the supporting factors for the sustainability of cattle farming. One of the keys to a successful pregnancy is the ability of bulls to mate cows. The bulls are maintained in a good performance so that they can act as superior bulls (Kurniawati et al., 2019).

Increasing cattle production can be carried out through natural and artificial mating. According to data presented by Rusdiana (2017), to increasing livestock production quickly and efficiently, Indonesia applies artificial insemination (Al) reproduction technology. The success factors of Al include semen from superior bulls, cows as acceptors, and reliable operators (Supriyanto, 2016). The Artificial Insemination Center (AIC) in Indonesia has a responsibility in maintaining superior bulls and producing good quality semen. Furthermore, AIC also plays a role in improving the genetic quality of the offspring of $\mathrm{Al}$ using good quality straws.

Good quality semen is produced by superior bulls with good reproductive performance. Apart from the influence of genetic traits, it is stated that the qualified semen of the superior bulls can be influenced by several factors, such as the bull's age, temperature and season, ejaculation frequency, and nutrition (Nirwana and Suparman, 2017). Bulls with poor reproductive performance can affect the quality of the semen produced. According to Kastelic (2013), subfertile bulls delay conception, prolong the calving season, reduce calf weaning weights, and increase the numbers of females culled, thereby resulting in economic losses and threatening the sustainability of a livestock operation.

The results of research conducted by Novianti et al. (2020) demonstrated the highly significant effect of breed on semen volume, motility, and concentration, especially in older males. That study compared the effect of breed on semen characteristics of aged bulls, including Madura, Bali, and Simmental bulls. Furthermore, the age of bulls is one of the important factors that influence semen quality (FuerstWaltl et al., 2006; Mahmood et al., 2014; Argiris et al., 2018). Nirwana and Suparman (2017) reported that age can have a significant effect on semen for Bali bulls.

In North America, most bulls offered for sale are 12 to 15 months old. Unfortunately, a large proportion of bulls are sexually immature at this time (Barth, 2018). Research by Mentari et al., (2016) on Simmental cattle at Ungaran AIC, showed a high percentage of abnormal sperm occurred in the young male group ( $<36$ months) and the older male group (72- $<108$ months). This study aimed to determine the effect of age and breed on the libido and quality of bull semen.

\section{MATERIALS AND METHODS}

\section{Research Material}

The main material of this study was semen of PO (Ongole grade bull), Simmental, and Brahman bulls, with a total amount of 15 aged 4-7 years old with normal reproductive organs obtained from RAIC UPTD BPBPTDK of the Yogyakarta Province Agriculture Office.

\section{Semen Collection and Evaluation}

Semen was collected using an artificial vagina as mentioned by Zemjanis (1962). The capacity of the libido was measured by calculating the time period from bull approaching teaser until ejaculate, producing semen into the artificial vagina and ready for further processing. Semen evaluation included volume, concentration, and motility using a spectrophotometer (Minitube $\odot$, Germany). Examination of viability and sperm abnormalities used the eosin nigrosine staining method. The head of living spermatozoa will remain transparent and the dead spermatozoa will be red in color. The samples were examined under a light microscope with a magnification of $400 x$.

\section{Data Analysis}

Data collection is done by 5 replicates which then analyzed using SPSS version 22.0 with ANOVA oneway method to determine the level of the significance $(P<0.05)$ on the mean difference of each libido value and the parameters of the quality of spermatozoa.

\section{RESULTS AND DISCUSSION}

The result showed that volume, concentration, motility, viability, semen abnormalities, and libido ( $\mathrm{Ta}$ ble 1.) in the various breed has no significant difference $(P>0,05)$. Bull's semen quality that consists of volume, concentration, motility, and viability in various age groups shows no significant difference $(P>0,05)$, however, the age group has a significant effect on semen abnormalities $(\mathrm{P}<0,05)$ (Table 2.). Age group that had most good semen quality is $5-6$ years old bull with semen volume $4.58 \pm 1.37 \mathrm{ml}$, concentration $1.91 \pm 0.36$ $\mathrm{x} 10^{9} / \mathrm{ml}$, motility $3.80 \pm 1.30$, viability $89.83 \pm 10.69 \%$, dan abnormalities $2.51 \pm 0.81 \%$. 
134 | Budiyanto et al.

Table 1 The Mean and Standard Deviation $(x \pm S D)$ of volume, concentration, motility, viability, sperm abnormalities, and libido in various breed bulls

\begin{tabular}{ccccccc}
\hline Bulls & Volume $(\mathrm{ml})$ & $\begin{array}{c}\text { Concentra- } \\
\text { tion }\left(10^{9} / \mathrm{ml}\right)\end{array}$ & $\begin{array}{c}\text { Motility } \\
(0-5)\end{array}$ & $\begin{array}{c}\text { Percentage of } \\
\text { Life }(\%)\end{array}$ & $\begin{array}{c}\text { Abnormali- } \\
\text { ties }(\%)\end{array}$ & $\begin{array}{c}\text { Libido } \\
\text { (seconds) }\end{array}$ \\
\hline PO & $5.64 \pm 3.35^{\mathrm{a}}$ & $2.20 \pm 0.24^{\mathrm{a}}$ & $3.40 \pm 1.67^{\mathrm{a}}$ & $89.34 \pm 10.51^{\mathrm{a}}$ & $6.08 \pm 4.48^{\mathrm{a}}$ & $394.60 \pm 193.63^{\mathrm{a}}$ \\
Brahman & $5.52 \pm 2.32^{\mathrm{a}}$ & $2.19 \pm 0.10^{\mathrm{a}}$ & $4.40 \pm 0.54^{\mathrm{a}}$ & $81.73 \pm 9.93^{\mathrm{a}}$ & $2.44 \pm 1.54^{\mathrm{a}}$ & $679.40 \pm 396.78^{\mathrm{a}}$ \\
Simmental & $6.04 \pm 1.56^{\mathrm{a}}$ & $2.02 \pm 0.51^{\mathrm{a}}$ & $3.80 \pm 1.30^{\mathrm{a}}$ & $84.62 \pm 5.63^{\mathrm{a}}$ & $5.34 \pm 3.70^{\mathrm{a}}$ & $237.20 \pm 110.22^{\mathrm{a}}$ \\
\hline
\end{tabular}

${ }^{a}$ Different superscript on the same row, showing significant differences $(P<0.05)$

Table 2 The Mean and Standard Deviation ( $x \pm$ SD) of volume, concentration, motility, viability, sperm abnormalities in the various age group

\begin{tabular}{cccccc}
\hline $\begin{array}{c}\text { Age } \\
\text { (years) }\end{array}$ & Volume $(\mathrm{ml})$ & $\begin{array}{c}\text { Concentration } \\
\left(10^{9} / \mathrm{ml}\right)\end{array}$ & Motility (0-5) & $\begin{array}{c}\text { Percentage of } \\
\text { Life }(\%)\end{array}$ & $\begin{array}{c}\text { Abnormalities } \\
(\%)\end{array}$ \\
\hline$\leq 4$ & $5.28 \pm 0.48^{\mathrm{a}}$ & $1.66 \pm 0.55^{\mathrm{a}}$ & $3.00 \pm 1.41^{\mathrm{a}}$ & $81.02 \pm 8.47^{\mathrm{a}}$ & $11.79 \pm 3.75^{\mathrm{a}}$ \\
$5-6$ & $4.58 \pm 1.37^{\mathrm{a}}$ & $1.91 \pm 0.36^{\mathrm{a}}$ & $3.80 \pm 1.30^{\mathrm{a}}$ & $89.83 \pm 10.69^{\mathrm{a}}$ & $2.51 \pm 0.81^{\mathrm{b}}$ \\
$\geq 7$ & $6.56 \pm 1.85^{\mathrm{a}}$ & $1.82 \pm 0.39^{\mathrm{a}}$ & $2.00 \pm 1.73^{\mathrm{a}}$ & $68.63 \pm 20.65^{\mathrm{a}}$ & $7.98 \pm 2.08^{\mathrm{a}}$ \\
\hline
\end{tabular}

ab Different superscripts on the same row, showing significant differences $(P<0.01)$

Bull's breeds used in this study were Brahman, PO, and Simmental. The results showed that breed did not affect the semen volume, concentration, motility, viability, semen abnormalities, and libido. According to Sumeidiana et al. (2007) and Ahmed et al. (2014) research; the sperm volume, concentration, and motility between bull breeds did not show significant differences. The sperm abnormalities also did not influenced by breed according to the studies of Vilakazi (2006) and Brito et al. (2002). The results of research by Menon et al. (2011) stated that the quality of spermatozoa is not influenced by the breed of cattle. The quality of sperm from different breeds had no different due to the similarity of the subgenus of the three breeds of cattle, namely the subgenus Bos (Williamson \& Payne, 1993).

The bulls in this study were grouped into three age groups, $\leq 4$ years old, $5-6$ years old, and $\geq 7$ years old. The results showed that age had no significant effect on motility. According to the research of Fuerst-Waltl et al. (2006) age did not affect spermatozoa movement but is affected by the temperature factor when the semen storage is carried out. Dewi et al. (2012) stated that the movement of spermatozoa was affected by the time of holding, and the low consistency of semen was influenced by the level of stimulation and the low quality of the feed given.

The age group did not significantly affect the volume, concentration, and viability of spermatozoa, but only had a significant effect on abnormalities of spermatozoa. In accordance to the research of Wiyanto et al. (2016); the age of Ungaran AIC bulls had no significant effect on volume due to genetic factors where the bulls come from different cows. Research by Dewi et al. (2012) stated that the semen concentration of Javanese bulls was not influenced by age as in our study. The decrease in the semen concentration can be caused by low feed quality. The results of the spermatozoa viability examination in this study were in accordance to the research of Melita \& Mulyadi (2014) that age and ejaculate frequency did not affect the percentage of live spermatozoa in Aceh bulls.

The spermatozoa abnormalities in this study were significantly affected by age. Some of the results of the sperm abnormalities examination are presented in Figure 1. The 5-6 years old age group has a low level of abnormality with a value of $2.51 \pm$ $0.81 \%$ compared to the $\leq 4$ years old age group ( 11.79 $\pm 3.75 \%)$ and $\geq 7$ years old $(7.98 \pm 2.08 \%)$. These results are in accordance to the research of Söderquist et al. (1996), that stated that there is a very 


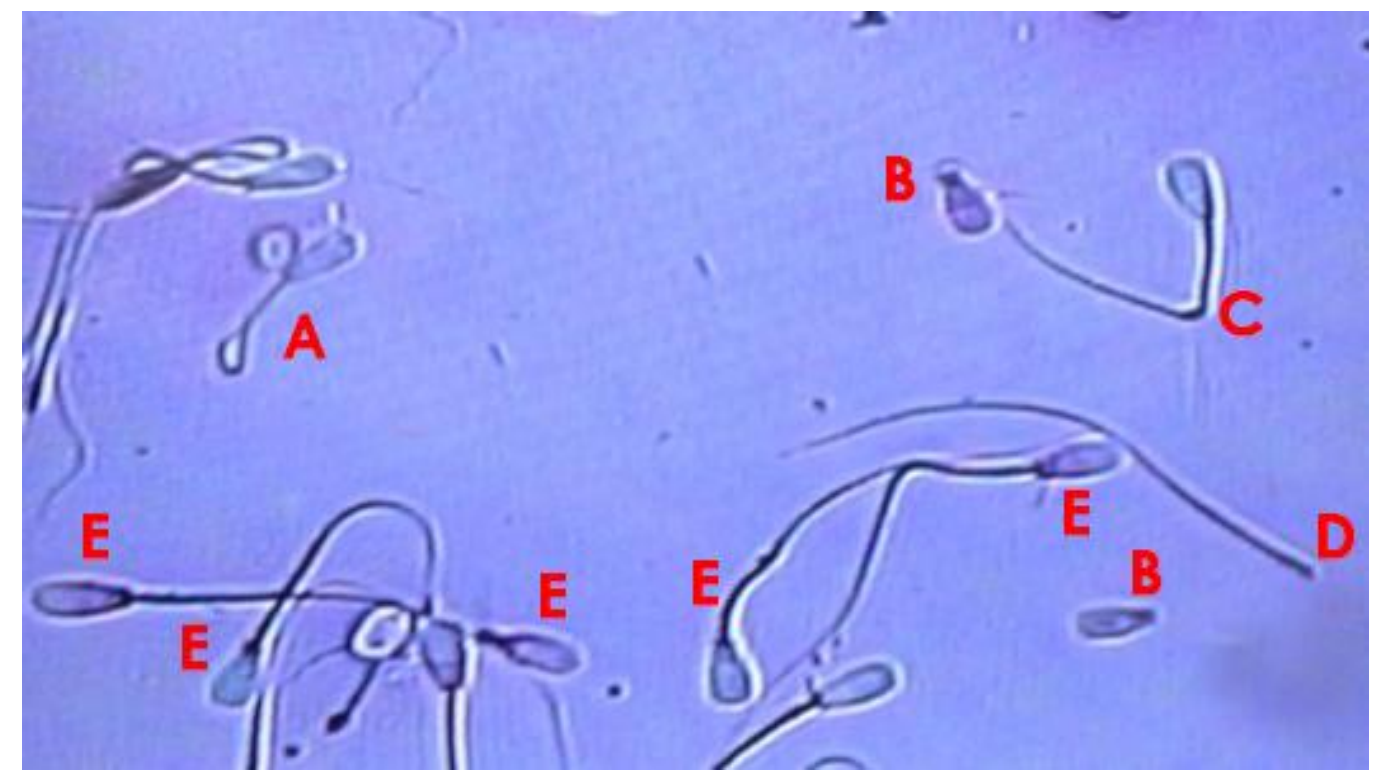

Figure 1 Results of sperm abnormalities examination; (A) curled tail, (B) missing tail, (C) bent tail, (D) missing head, and (E) normal spermatozoa

significant effect of age on spermatozoa abnormalities. Dowsett \& Knott (1996) stated that there was an increase in spermatozoa abnormalities in horses aged over 11 years due to the reduced ability of the spermatogenesis process and epididymal function. Cows with a very young age produce sperm that are more immature in morphological abnormalities (Amann et al., 2000).

Semen volume, concentration, motility, and abnormalities of spermatozoa that meet normal standards may be caused by feed given, environmental adaptation, frequency of ejaculation, collection methods, and prestimulation (Garner \& Hafez, 2010; Feradis, 2010; Ismaya, 2014). The quantity and quality of fresh semen were influenced by several factors, namely genetics, age, feed, temperature or season, frequency of ejaculation, libido, physical factors, transport, scrotum size, and health (Ismaya, 2014).

It can be concluded that the breed did not affect the libido value and the semen quality of bulls. Volume, concentration, motility, and viability in various age groups did not show significant differences, but age groups had a significant effect on semen abnormalities. The age group that produces the best semen quality is the 5-6 years old group bulls.

"All authors declare that there are no conflicts of interest".

\section{REFERENCE}

Ahmed KU, Islam MR, Talukder MK, Rahman Z, Hossain MM, Bhuiyan MM. 2014. Influence of breed, age and collection interval on semen quality of Al dairy bulls in Bangladesh. Bangladesh Research Publications Journal 10(3): 275-282.

Amann RP, Seidel Jr GE, Mortimer RG. 2000. Fertilizing potential in vitro of semen from young beef bulls containing a high or low percentage of sperm with a proximal droplet. Theriogenology 54(9): 1499-1515.

Argiris A, Ondho YS, Santoso SI, Kurnianto E. 2018. Effect of age and bulls on fresh semen quality and frozen semen production of Holstein bulls in Indonesia. In IOP Conference Series: Earth and Environmental Science 119(1): 12-33.

Barth AD. 2018. Review: The use of bull breeding soundness evaluation to identify subfertile and infertile bulls. Animal 1-7.

Brito LFC, Silva ADEF, Rodriguez LH, Vieira FV, Deragon AG, Kastelic JP. 2002. Effects of age and genetic group on characteristic of scrotum, testis, and testicular vascular cone and on sperm production and semen quality of Al bulls in Brazil. Theriogenology 58: 1175-1186.

Dewi AS, Ondho YS, Kurnianto E. 2012. Kualitas semen berdasarkan umur pada sapi jantan jawa. Animal Agriculture Journal 1(2): 126-133. 
Dowsett KF, Knott LM. 1996. The influence of age and breed on stallion semen. Theriogenology 46(3): 397-412.

Feradis MP. 2010. Bioteknologi Reproduksi pada Ternak. Alfabeta. Bandung.

Fuerst-Waltl B, Schwarzenbacher H, Perner C, Sölkner J. 2006. Effects of age and environmental factors on semen production and semen quality of Austrian Simmental bulls. Animal Reproduction Science. 95(1-2): 27-37.

Garner DL, Hafez ESE. 2000. Spermatozoa and Seminal Plasma. In: Hafez B, Hafez ESE (eds). Reproduction In Farm Animals. 7th ed. Lippincott Williams and Wilkins. South Carolina. p96-109.

Ismaya. 2014. Bioteknologi Inseminasi Buatan Pada Sapi Dan Kerbau. Gadjah Mada University Press. Yogyakarta.

Kastelic JP. 2013. Male involvement infertility and factors affecting semen quality in bulls. Animal Frontiers 3(4): 20-25.

Kurniawati R, Gariri PN, Safitri MV, Maskur M, Nurkholis N, Nusantoro S. 2019. Evaluasi Pakan Sapi Jantan dalam Kegiatan Pembibitan Sapi Bali (Bos sondaicus). Jurnal Nutrisi Ternak Tropis 2(2): 47-50.

Mahmood SA, ljaz A, Ahmad N, Rehman H, Zaneb H and Farooq U. 2014. A study on relationships among age, body weight, orchidometry, and semen quality parameters in adult Cholistani breeding bulls. The Journal of Animal and Plant Sciences 24: 380-384.

Melita D, Mulyadi A. 2014. Pengaruh umur pejantan dan frekuensi ejakulasi terhadap kualitas spermatozoa Sapi Aceh. Jurnal Medika Veterinaria 8(1).

Menon AG, Barkema HW, Wilde R, Kastelic JP, Thundathil JC. 2011. Associations between sperm abnormalities, breed, age, and scrotal circumference in beef bulls. The Canadian Jornal of Veterinary Research 75: 241-247.

Mentari FK, Ondho YS, Sutiyono S. 2016. Pengaruh umur terhadap ukuran epididimis, abnormalitas spermatozoa dan volume semen pada Sapi
Simmental di Balai Inseminasi Buatan Ungaran. Animal Agriculture Journal. 3(4): 523-528.

Nirwana N, Suparman S. 2017. The effect of male age on the quality of Bali cattle fresh semen. Chalaza Journal of Animal Husbandry 2(2): 13-18.

Novianti I, Purwantara B, Herwijanti E, Nugraha CD, Putri RF, Furqon A, Septian WA, Rahayu S, Nurgiartiningsih VM, Suyadi S. 2020. Effect of breeds on semen characteristics of aged bulls in the Indonesian National Artificial Insemination Center. Jurnal Ilmu-Ilmu Peternakan 30(2): 173-179.

Rusdiana S. 2017. Program SIWAB untuk meningkatkan populasi sapi potong dan nilai ekonomi usaha ternak. Forum Penelitian Agro Ekonomi 35: 125-137.

Söderquist L, Janson L, Håård M, Einarsson S. 1996. Influence of season, age, breed and some other factors on the variation in sperm morphological abnormalities in Swedish dairy Al bulls. Animal Reproduction Science 44(2): 91-98.

Sumeidiana I, Wuwuh S, Mawarti E. 2007. Volume Semen dan Konsentrasi Sperma sapi Simmental, Limousin dan Brahman di Balai Inseminasi Buatan Ungaran.http:// eprints.undip.ac.id/26182J. Indon.Tr op.Anim. Agric. 32 [2] June 200. Download: January 19, 2017.

Supriyanto. 2016. Faktor - Faktor yang Mempengaruhi Keberhasilan Program Inseminasi Buatan (IB) pada Ternak Sapi Potong. Jurnal Triton 2: 69-84.

Vilakazi DM. 2006. Factors affecting the quality of semen of Al dairy bulls in South Africa. Disertasi S3. Sekolah Pascasarjana, University of Pretoria. Lynnwood Rd.

Williamson G, Payne WJA. 1993. Pengantar Peternakan di Daerah Tropis. Universitas Gadjah Mada. Yogyakarta.

Wiyanto A, Mas IK, Sutiyono B. 2016. Pengaruh umur terhadap ukuran testis, volume semen dan abnormalitas spermatozoa pada Sapi Simmental di Balai Inseminasi Buatan Ungaran. Animal Agriculture Journal 3(2): 292-299. 